\title{
Thick Translation Strategies of Social Science Texts: A Case Study of the C-E Translation of China's Solution to Its Ethno-National Issues
}

\author{
ZHANG Jianping \& HUANG Xiya \\ School of Foreign Languages, Jiangxi University of Science and Technology, China
}

Received: May 11, 2021, Accepted: June 6, 2021 Published: November 30, 2021

To cite this article: ZHANG Jianping \& HUANG Xiya. (2021). Thick Translation Strategies of Social Science Texts: A Case Study of the C-E Translation of China's Solution to Its Ethno-National Issues. Asia-Pacific Journal of Humanities and Social Sciences, 01:3, 181-189, DOI: 10.53789/j.1653-0465.2021.0103.020

To link to this article: https://doi.org/10.53789/ j.1653-0465.2021.0103.020

Abstract: Among the Understanding China Series published by China Social Science Press, this book focuses on the global issue of ethnic problems and examines the theory and practice of how China addresses its ethnic problems from a macro perspective. Based on comparative and empirical studies, it also offers specific solutions to ethnic problems in contemporary China. In 2017, the book was granted by the National Social Sciences Fund for the Project of Translating Chinese Academic Works. And in 2019, the English version of China's Solution to Its Ethno-National Issues was launched by Springer, a world-renowned publisher for sci-tech books. This article studies the specific use of thick translation and norms in translating academic works to spread Chinese culture and show the real China to the world. In an attempt to figure out how to convey the writer's thoughts in a better way and make them accepted widely, it analyzes the cases of thick translation, both inside and outside translated texts.

Keywords: thick translation; Translating Chinese Academic Works; thick translation inside translation; thick translation outside translation

Notes on the contributors: Zhang Jianping holds a doctorate degree in Arts. He is associate professor of Jiangxi University of Science and Technology. His academic interest lies in scientific and technical translation. Huang Xiya is a postgraduate student of Jiangxi University of Science and Technology. His academic interest lies in translation theory and practice.

\section{社會科學文本的深度翻譯策略 以《中國特色解決民族問題之路》的英譯為例}

\author{
張建平 黄西亞 \\ 江西理工大學外國語學院
}

摘 要: 《中國特色解決民族問題之路》為中國社會科學出版社《理解中國》叢書之一。該書以宏觀的視野, 圍繞民 族問題這一全球性的話題, 論述中國特色解決民族問題正確道路的理論與實踐。該書於 2017 年獲批國家社科基 
金中華學術外譯專案。國際著名的科技圖書出版公司斯普林格出版社於 2019 年推出了該書的英譯本 China's Solution to Its Ethno-national Issues。本文詳細考察了英譯本中深度翻譯策略與學術翻譯規範的具體表現, 通過研究其 譯文內與譯文外深度翻譯例子, 試圖找出此類著作在英譯過程中如何更好傳達原作者思想的方法, 以達到傳播中 國文化、展示中國形象的目的。

關鍵詞: 深度翻譯; 中華學術外譯; 文本內深度翻譯; 文本外深度翻譯

\section{引言}

改革開放以來, 中國與世界的聯繫越來越緊密, 經濟騰飛、日新月異成為中國在國際社會的代名詞。但 與此同時,世界上仍有許多人對中國的印象停留在上個世紀的貧窮、落後之上; 而且, “世界舆論西強我弱局 面尚未根本改變”, 我們想要“引領世界輿論絕非易事,需要加強頂層設計,兼顧各方, 既有明確的大方向, 又 有多角度多層次的話題”。(1)

在中國社會科學出版社社長兼總編輯趙劍英看來, 我們以更加寬容、友好的心態融人世界時, 自己卻沒 有被客觀真實地理解。 ${ }^{2}$ 這樣的嚴重不對等, 造成了國際上長期存在的對中國的妖魔化和汗名化。在這樣的 背景下, 中國社會科學出版社策劃出版了“理解中國” 叢書, 以“發揮學術優勢, 講好中國故事” 為追求, 選取 國內外讀者關注的重大理論和實踐問題,從經濟、政治、宗教信仰、民族政策、生態環境治理,以及中國古代 文明、哲學、藝術等多方面設置選題, 由各學科權威專家撰寫, 以深人淺出、通俗易懂的寫作方式打造出一套 學術著作精品, 向國内外讀者闆述中國的歷史與現實。該叢書注重提煉中國特色, 闆釋中國道路、中國理 論、中國制度,且具有國際和比較的視野。

如此來看,講好中國故事,傳播好中國聲音是當代中國文化工作者當仁不讓的重大使命, 同時中國學術 國際化既是中國文化走出去的重要途徑, 也是配合中國崛起不可或缺的部分。《中國特色解決民族問題之 路》系“理解中國” 叢書中的一部, 作者郝時遠先生在大量調查研究的基礎上, 以全面客觀的眼光和扎實詳盡 的筆觸為我們論述了中國的民族關係發展史, 從具體人微的實證, 在國際比較的視域中, 分析了中國解決民 族問題的當代主題,即中國各民族人民在物質生活層面縮小差距、共用發展,在精神生活層面尊重差異、認 同一體。

像《中國特色解決民族問題之路》這樣的主題圖書, 反映的是時代重大課題, 作者都是社會精英、領域權 威, 能被翻譯成外文出版,必定思想内涵深刻, 觀點內容權威。 ${ }^{3}$ 作為傳播中國聲音, 展現中國風貌的載體, 主 題圖書的傳播過程也充滿挑戰。其中首當其衝的便是翻譯問題。在當今時代, 我們既要繼續翻譯世界, 也 要加強翻譯中國, 这這是翻譯研究呈現出的新特點。但整體來說, 中文社科文獻的翻譯缺少學術界的重視, 因此如何能讓這本解決民族問題的 “法寶” 為國外專家學者、政府官員所接受, 是對譯者能力的重大考驗。

翻譯在廣義上被認為是一種跨文化交際活動，“目標語讀者導向”的理念應貫穿于翻譯過程的始終。(5) 張 譯本的《中國特色解決民族問題之路》採用了大量深度翻譯策略, 使得行文更加符合外國讀者的閱讀習慣, 同時也將原文中大量出現的中國特色詞彙、文化負載詞等處理得更加明白易懂, 幫助外國讀者清除了閱讀 障礙。由此,這部代表中國智慧、貢獻中國方案的著作也得以發揮更加廣泛的影響力。

\section{一、深度翻譯}

深度翻譯( thick translation) 來源於英國分析哲學家吉伯特・賴爾的“深度描寫”理論。“深度描寫”被引 
人人類學之後,為不同文化之間的交流提供了一種嶄新的視角。之後美國普林斯頓大學哲學教授阿皮亞將 這一理論應用于翻譯學研究之中, 提出了 “深度翻譯” 的概念。其主要含義為“深度語境化,在翻譯文本過程 中採用添加註腳、注釋、評注等方法, 以便將文本置於具有豐富內涵的文化與語境之中, 進而使被文字遮蔽 的意義和譯者的意圖互相融合”。簡單來說, 深度翻譯便是譯者除譯文之外, 仍需添加其它注釋、評注、說明 等詮釋性材料, 以達到使目標讀者更易理解譯文的目的。譯者通過深度翻譯的種種手段和策略, 為目標讀 者構建出理解、感悟來源語言文化的平臺; 深度翻譯解決的是文化理解層面的問題, 它是讀者與來源語言文 化之間的橋樑。

自阿皮亞教授提出 “深度翻譯” 這一概念以來, 翻譯界得以用一個全新的視角來審視翻譯活動。但阿皮 亞教授的 “深度翻譯”更偏向於一種指導性的原則, 眾多翻譯學者在自己的翻譯實踐中豐富了這一理論。赫 爾曼斯提出實施深度翻譯的兩個途徑: 評注和修辭闡釋學; 深度翻譯被引入國內的時日尚短, 但相關研究已 經出現不少:2005 年,譚載喜教授將“thick translation”翻譯為“增量翻譯”,確實符合深度翻譯常用策略— 添加注釋的特徵, 自此之後, 關於深度翻譯的研究逐漸多了起來; 張佩瑤也提出了背景描述、解釋、深厚鋪熱 等具體操作方法來幫助讀者跨越理解方面的鴻溝; ${ }^{7}$ 李雁在《<紅樓夢>法譯本的 “深度翻譯” 及其文化傳遞》 中,根據“realia 理論”和“副文本”理論總結出 “深度翻譯” 的類型和具體實施方法,使這種新興的翻譯理論 具有可操作性。斻明武、王煙朦運用法國社會學家布迪厄的 “資本” 概念審視任以都英譯版《天工開物》, 發 現任以都運用的深度翻譯策略乃是特定社會歷史背景下文化資本、社會資本、象徵資本和經濟資本相互作 用的產物。

但我國現有關於深度翻譯在譯本中體現的研究還多數集中於外譯中作品,在提倡中國文化“走出去”的 大背景下, 我們還應加強中譯外作品中深度翻譯的研究, 對譯者的翻譯動機、翻譯策略以及希冀達到何種目 的進行䦴釋。由此來看,張譯本 China's Solution to Its Ethno-national Issues 便十分值得探討。

\section{二、《中國特色解決民族問題之路》的英譯本中深度翻譯策略的應用}

融通中外, 就是我們傳播的概念範疇表述既要符合中國國情,有鮮明的中國特色; 又要與國外習慣的話 語體系、表述方式相對接,易於為國際社會所理解和接受 ${ }^{\mathbb{1 0}}$ 。深度翻譯策略想要達到的目的正與此契合。

本文探討的深度翻譯策略主要分為文本内深度翻譯與文本外深度翻譯。前者主要採用加注的方式為 文本增加更多詳細資訊, 如拼音加注、註腳等, 讀者通過此類加注會對譯文有更加深刻的認識, 減少讀者閱 讀譯文時的理解障礙; 本文考察的文本外深度翻譯主要是譯者注。譯者在翻譯前對原文整體風格、出版目 的、譯文受眾等都做了具體研究, 並將其在譯者注中加以說明。可以說, 譯者注是讀者通過譯文理解原著的 極大助力。

\section{(一) 文本内的深度翻譯}

譯注是譯文內深度翻譯的集中體現, 同時也是深度翻譯最直觀的體現。 ${ }^{\mathbb{1}}$ 《中國特色解決民族問題之路》 一書中出現了大量的人名、地名及歷史事件等文化負載詞,這些看似簡單的詞卻包含了豐富的地理、歷史、 文化、社會資訊。原文讀者在讀到這些詞時能夠心領神會, 迅速體會到這些詞語背後的含義, 但對於譯文讀 者來說, 直接翻譯而成的英語並不能準確傳達其隱藏含義, 甚至會讓讀者一頭霧水。因此, 譯者往往在翻譯 過程中添加一些解釋性的背景資訊, 以使譯文更加明白易懂。

1. 拼音加注 
Asia-Pacific Journal of Humanities and Social Sciences

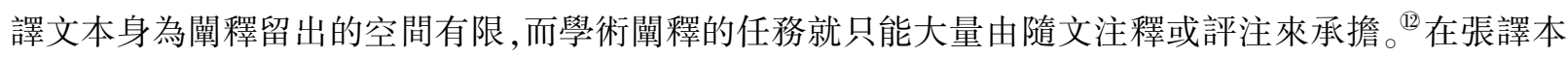
中,多次出現了拼音加注的方法,主要用於表述歷史上已經約定俗成的特有詞彙, 先用拼音將該詞彙表示出 來,再把英語解釋置於其後。如:

例 1 : 清朝政府對邊疆地區的治理雖然承襲了“因俗而治” 等羈縻政策,但是通過制度和法律形式實施統 治的治理能力顯著增強。 ${ }^{13}$

譯文:Although the Qing court continued to apply the Jimi system, an autonomous administrative and political organization system, to govern the frontier regions, the Manchu ruler's governance capacity in the border areas had been significantly strengthened with the enhanced composite national strength.

經查閱資料, “羈縻政策” 是自秦朝建立郡縣制起, 到宋、元交替時期前, 中央王朝籠絡少數民族使之不 生異心而實行的一種地方統治政策。通過這種政策,處理中央與地方少數民族聚居的關係, 以維繫中央集 權制度的統治。譯者先將其音譯,而後利用同位成分進行解釋: an autonomous administrative and political organization system。如此一來,譯文讀者便對中國歷史上的這一重要民族制度有了初步瞭解。

例 2 : 這就如同由西北地方回族、撒拉族經營的牛肉拉麵, 在全國範圍的名聲是 “蘭州拉麵” ( 2 萬 家)、“青海拉麵” (3 萬家)一樣,而且已經發展到新加坡、馬來西亞等國。

譯文:For example, “Lamian” ( literally “hand-pulled noodles” whose preparation involves taking a lump of dough and repeatedly stretching it to produce a single long noodle, was first created by the Muslim Hui People in northwestern China. Eateries serving Lanzhou-style or Qinghai-style “Lamian” are very popular throughout China where they have formed a staple diet for centuries. They are increasingly found in the Chinatowns of Singapore and Malaysia.

拉麵是中國傳統麵食,國外並無對應之物。但如果將“拉麵”簡單音譯成“Lamian”, 譯文讀者便會 不知所云, 可能無法傳達其文化內涵; 譯文先將“Lamian” 寫出, 之後用流暢的語言補充了拉麵的製作過 程,清晰明白,一目了然。雖稍顯繁瑣,但為了準確傳達語義,便不得不做出一部分妥協。

例 3: 隱藏在廓爾喀背後被稱為 “披楞” 的勢力, 卻使清朝政府一直摸不著頭腦。直到近半個世紀之 後鴉片戰爭爆發,清朝政府才明白了“披楞即系英國”。

譯文:During the armed conflict, the so-called Phe-rang forces (literally means “foreigners” in the Tibetan language) secretly assisted the Gurkhas. It was until the eruption of the First Opium War in 1840 that the Qing government came to realize that “the Phe-rang forces” were actually the British colonists.

譯文先將“披楞” 音譯（the so-called Phe-rang forces）, 然後用括弧說明該專有名詞的來由, literally means “foreigners” in the Tibetan language (藏語中指外國人)。對於此類明顯帶有地方特色的詞語, 忽 略不譯和強行解釋都不是最得當的方法。如此這般, 將詞語音譯和英文解釋一併寫出, 才能讓譯文讀 者有更加全面、清晰的瞭解。

\section{2. 註腳}

例 4 : 而時隔一年後的烏魯木齊“ $7 \cdot 5$ ”事件,則以更加血腥暴力的場景展現在國人面前 $\cdots . . .$.

譯文: On 5 July 2009, a series of violent riots broke out in Ürümqi, the capital city of the Xinjiang Uyghur Autonomous Region in northwestern China. ${ }^{3}$ (此處的“3”為譯本中的註腳編號。)

譯者依照原文將句子翻譯出來,並在譯文中對烏魯木齊作了簡要介紹。但對中國人民來說觸目驚 心、傷痕累累的“7 . 5”事件,外國讀者卻知之甚少。鑒於此,譯者在註腳中對這一事件再次進行說明： 
3: “The first day's rioting, which involved at least 1,000 Uyghurs, began as a protest but escalated into violent attacks that mainly targeted Han people. A total of 197 people died, among those killed most of them are Hans, with 1,721 others injured and many vehicles and buildings destroyed.”

“197 人死亡, 1721 人受傷,多處建築遭到毀壞”, 冰冷的數字背後是一條條鮮活的生命。無論恐怖 暴徒如何掩飾, 都無法改變此次事件暴露出來的血腥、恐怖的本質。有了此條註腳, 譯文讀者便更能瞭 解 “ 7 - 5”事件的真相, 這並非他們印象中的和平遊行, 而是赤裸裸地煽動民族仇恨, 以鮮血和生命的代 價來實現暴徒身後那些陰謀家們不可告人的目的; 也更能理解中國政府為何堅決、嚴庽打擊一切形式 的恐怖主義活動, 打擊一切分裂國家、破壞民族團結、破壞社會穩定的犯罪活動了。所以說這條註腳是 十分有效且必要的。

例 $5: \cdots \cdots$ 包括 1771 年不堪忍受沙俄統治毅然率領蒙古土爾扈特部眾東歸祖國的渥巴錫, 也在此 受到乾隆皇帝的接見和封授。

譯文:It was in the main hall of the architectural complex that Emperor Qianlong received Ubashi Khan, a Torghut prince, who led his tribesmen on their massive migration back to China from Russia.

原作者在本節中著重敘述了清政府在處理邊疆少數民族事務方面的成就,包括制定律法,參與當 地宗教事務, 乃至在邊疆地區設置機構, 轄領區域事務。自此民族和睦, 中原地區成百上千年的遊牧民 族威脅消弭殆盡。而這其中, 十八世紀土爾扈特部的回歸則更能體現清政府在民族事務上的成就。 “土爾扈特部回歸”這一事件已編人中學歷史教材, 中國讀者必不會陌生。而讀到此處的外國讀者,並 不能通過 “Torghut”這幾個字母聯想到其背後的深刻含義, 因此譯者在正文下方添加了一段註腳, 用以 向讀者解釋土爾扈特部的來歷以及回遷的緣由: “The Torghut was a Mongol clan who were compelled to migrate westward towards the end of the Ming dynasty (1368-1644) after repeated attacks by the Zhungaer tribe. They then settled in the lower reaches of the Volga in Russia. There for a long time they were subjected to oppression and plundered by the government of Tsarist Russia and unable to stand this any longer, they finally decided to migrate back to China.” 譯者註腳內容與原作者前文所述相互印證, 從側面反映了清政府民族 政策的成功,體現出民族和諧、團結一心的局面,有理有據, 令人信服。通過閱讀註腳, 讀者對“Torghut” 有了更加全面、深刻的理解, 知曉民族和諧的傳統早已深深紮根中國土地上, 進而對之後中國共產黨的 民族政策從何而來有了初步瞭解。

\section{3. 隱性深度翻譯}

除卻添加注釋、注腳之外, 張譯本中還大量出現了另一種深度翻譯策略, 即 “隱性深度翻譯”。有感 於“加注”等方式的局限性,四川大學教授曹明倫先生在前人理論和大量翻譯實践的基礎上, 總結出了 “隱性深度翻譯” 這個概念, 其核心含義就是譯者無需在譯文正文以外的地方添加詮釋性材料, 而是在 “正確判㫁譯文讀者認知語境的前提下,在譯文正文中增加有其意而無其詞的說明性字詞”,如此一來， 譯文便會在語義層面和表達效果上更加貼近原文,或者說“譯文對譯文讀者的影響方式和影響程度更 接近于原文對原文讀者的影響方式和程度”。 從這點來說, 隱性深度翻譯與著名翻譯學家尤金・A - 奈 達( Eugene A. Nida) 提出的“動態對等” (dynamic equivalence) 原則有異曲同工之妙, 同時, 也與譯者在 譯者注中表達的想法不謀而合。

例 6 : 從延安走來

譯文:The Ethno-national Policies of the CPC during its Time based in Yan' an: 1935-1948 


\section{(中國共產黨在延安時期的民族政策)}

原文漢語標題簡明扼要, 突出了該節主題, 漢語讀者對延安這個地名的歷史文化内涵( 中國革命的 落腳點和出發點) 也不存在理解上的障礙。如果按照原文形式直譯, 該標題則為 Departing from Yan’an. 但這種譯法至少存在以下問題: 首先, 譯文讀者最直觀的感受是莫名奇妙,因為多數英語讀者對 Yan'an 這個地名都會感到陌生; 其次, 漢英標題的建構方式存在較大不同, 漢語標題常用動詞短語結構, 英語 則常用名詞話短語以及與介詞搭配的“名詞+介詞結構”。

延安是中國共產黨歷史上不容忽略的一個地名, 代表著一種精神, 象徵著一種傳承。原書前言部 分敘述了在世界動盪不安、國內局勢不明的情況下, 中國共產黨是如何在延安艱難探索出前進之路的。 延安是中國共產黨走向成熟的重要拐點,這一時期的政策也是中國國內外學者研究的重點。如果按照 字面意思直接翻譯, 不僅會讓譯文讀者一頭霧水, 也無法準確傳達出前言部分的主要内容, 實在不是可 取的做法。考慮到以上因素,此處譯者將前言標題翻譯為“The Ethno-national Policies of the CPC during its Time based in Yan'an: 1935-1948 (中國共產黨在延安時期的民族政策)”便顯得尤為巧妙,讀者一眼 就能得知這一部分的主要内容, 將時間一同放人譯文也同樣值得稱讚,這讓對中國共產黨不太瞭解的 外國讀者心中有了大致的時間線,消除了一定的陌生感。

例 $7:$ 這支新興的政治力量, 於 1931 年在江西瑞金建立了革命根據地。

譯文:After being forced out of the Jinggang Mountains by the Kuomintang army, the Communists fled to Ruijin, taking advantage of its relative isolation in the rugged mountains along Jiangxi's border with Fujian.

中國讀者對延安、井岡山、瑞金這些地名十分熟悉, 因為這些地方見證了中國共產黨從弱小到強 大,一步一個腳印的成長歷程。中國讀者看到瑞金,腦海裡會自然想起早期中國共產黨在國民黨反動 派圍剿下蔇難生存, 頑強抵抗的場景, 而同樣的感受卻幾乎不會出現在對中國知之甚少的外國讀者身 上。因此,翻譯時便要做出一些調整。“深度翻譯其實質是增量翻譯……其概念本身包含了實施深度 翻譯的方法”, 譯者在處理這段文字時,特意對瑞金的地理位置以及帶來的優勢作了簡要介紹, 而增加 的內容絕非無用:一者,讀者通過譯文中詳細的介紹對瑞金會有更加直觀的印象; 二者, 所增加內容為 讀者勾勒出一副險峻、崎嶇的地形,在表現出瑞金地理特徵的同時,也讓譯文讀者更深刻體會到當時共 產黨人生存環境之惡劣,可謂䇤路藍縷、艱辛異常。這樣的處理省卻了添加注釋的繁瑣,使得行文更加 流暢, 同時也傳達出了更深層次的含義,一舉兩得。

例 8: 在英國侵略軍的火炮和梅可馨機關槍面前, 藏族軍民守土有責的頑強抵抗精神, 令英國人也 感到吃驚: “他們幾十個人也敢向比他們大得多的力量發起進攻,不顧一切地全部戰死。幾個強征來的 農民為了保衛一個村莊,也會像古羅馬的愛國志士一樣獻身。

譯文:Even the British invaders were terribly shocked by the tenacious resistance of the Tibetans. Edmund Candler, who gained an appointment as the Daily Mail correspondent accompanying the expeditionary force into Tibet, later recalled the combat in his account of the expedition: "the Tibetan soldiers, who were merely armed with swords and gingals, made their tragic and heroic last stand against the well-equipped British troops, who were experienced veterans of mountainous border warfare. In spite of the great disparity in military strength, the Tibetan soldiers, who actually lacked discipline and training, have the guts to sacrifice their blood and flesh for the protection of their home village."

在原文中, 作者將引文出自何人何處在註腳中作了說明。譯者在此處把註腳中的内容(引文出處: 
艾德蒙・坎德勒:《拉薩真面目》) 移到譯文正文中, 並對艾德蒙・坎德勒的身份作了進一步說明 (Edmund Candler, who gained an appointment as the Daily Mail correspondent accompanying the expeditionary force into Tibet）,使得原文所述內容更有說服性,表現了中國人民反抗外來侵略,誓死保家 衛國的決心 ,同樣具有錦上添花的作用。

例 9:“跪拜”與“行禮”的悲歌

譯文:The Turn of Dynastic Fortune: from prosperity to decline

不同語言有不同的話語修辭方式。中文修辭重感覺性和概括性的話語,傾向於根據所見所聞和直 覺抒發內心感悟和情緒, 喜用語義迂回模糊的表達, 以極凝練的詞傳達極豐富的含義。而受說話者思 維影響, 英語修辭偏愛清晰、精確的語言, 重說理分析。該原文標題屬典型的詩化標題, 完美地體現了 漢語的特點:多用動詞,具體可感; 但該標題如直譯則為: The elegy of “kowtow” and “salute”, 由於英文 抽象性的特點,很多英語讀者無法理解其含義。基於此,譯者將其調整為 The Turn of Dynastic Fortune: from prosperity to decline,意為“王朝命運從繁榮到衰落的轉變”,簡潔明瞭, 意思準確,也避免了過多注 釋所帶來的行文不暢。

\section{（二）文本外的深度翻譯一一譯者注}

文本內深度翻譯是最常用, 也最直觀的手段; 但同時, 譯文外深度翻譯的重要性也不容忽視, 可以 幫助讀者加深對原作的體認, ${ }^{10}$ 同時讓譯文讀者可以更清晰地瞭解原作, 甚至原文語言所在的文化。

譯者認為,譯文的表達形式靠近原文 (按原文的結構和用詞), 還是遠離原文 (脫離原文的結構和用 詞,用自己的語言表達原文的意思), 取決於哪種形式更有利於翻譯所服務的社會目標的實現。譯者在 動手翻譯之前, 對原書的風格、内容以及期望產生的效果作了全面分析。譯者認為, 原書是一本學術著 作, 其譯文必須做到客觀準確、用語樸實。為了講好中國故事, 展現真實、立體、全面的中國、增進國外 讀者對中國的瞭解與理解,為中國發展營造更好的國際環境,必須採取適當的策略使得譯文更易為外 國讀者所接受, 以達到對其產生有效影響的宣傳效果。譯者注闡明了譯者翻譯過程中的總體指導思 想,並列舉了大量為達到最佳效果而做出的調整,用心之處, 可見一斑。以下為作者從譯者注中節選的 片段, 以支持上述觀點。

例 10:1936 年的歲末,世界終於關注了中國,國民黨將領張學良、楊虎城發動了抗日救國的“兵 諫”, 扣押了蔣介石。

譯文:It was until late 1936 that the world finally diverted its attention to China. On 12 Dec. 1936, Chiang Kai-shek, chairman of the KMT - controlled Nationalist Government of China, was arrested by Zhang Xueliang, a former warlord of Manchuria and commander of the Northeastern Army, in order to force Chiang to enter into a cease-fire with the CPC and form a united front against Japan.

說明:原文中的“兵諫”如直譯則為 forced remonstration，一般英文讀者還是會覺得費解。這就出現 了以上提到的譯人語詞義空缺。譯者將原文的 “兵諫” 作了措辭上的微調: in order to force Chiang to enter into a cease-fire with the CPC and form a united front against Japan (用武力逼迫蔣介石停止打內戰, 並與中共建立抗日統一戰線)。

例 11 : “甲午折戟”痛失臺灣

譯文:The First Sino-Japanese War and Japan's Annexation of Taiwan 
( “第一次中日戰爭”及日本吞併臺灣)

說明:西方人一般將“甲午戰爭” 統稱為 “第一次中日戰爭”。為了英語讀者閱讀起來更加順暢, 譯 者沒有採用音譯法 The Jiawu War, 因為這樣勢必得解釋何謂“甲午” (中國傳統的天干地支等資訊), 增 加讀者的閱讀負擔。

例 12 : “一盤棋”中“兩個大局”

譯文:Deng Xiaoping's Phased Development Approach: from Coastal Areas to Interior Provinces

說明: “美文” 是漢語修辭的一個突出特點, 指文采洋溢、辭藻華麗、文筆生動、大量使用比喻意象的 文字。駢體文的影響和重感性的思維形成國人表達的詩意傳統和美文傾向, 喜用遠離世俗的詩化語 言。該標題如直譯則為 “two overall imperatives” in “a game of chess”, 西方受眾會覺得這種文字缺乏有 用資訊和相關性。因此, 譯者將其改寫成了 Deng Xiaoping's Phased Development Approach: from Coastal Areas to Interior Provinces( 鄧小平的漸進式經濟發展戰略:從沿海地區到内陸地區)。

\section{結語}

本文對張譯本《中國特色解決民族問題之路》的深度翻譯策略進行了細緻考察和全面研究。研究 發現, 譯者在翻譯過程中並不拘泥于原文的固定形式, 而是採用多種方法處理譯文, 以求達到最佳的表 意和宣傳效果。隨著綜合國力不斷增強, 中國也越來越走向世界舞臺的中央,一舉一動都備受關注。 但是關注的人中總是不乏惡意揣測、抹黑中國之人, 企圖通過歪曲中國民族事務真相來攻擊中國國家 形象。在中華民族走向復興的關鍵時期, 中國需要比以往任何時候都要更加積極主動地講述中國的故 事。作為世界第二大經濟體, 中國要迅速習慣面對世界講述自己的觀點、立場。

較之文學翻譯或科技翻譯, 社科文獻翻譯在國內外翻譯研究界稱不上是顯學。 ${ }^{18}$ 但社科專著在傳達 中國聲音、表達中國態度方面又有著極其重要的作用。《中國特色解決民族問題之路》一書對中國民族 問題作了客觀、詳盡的敘述, 對分享成功經驗和澄清事實真相都起著巨大作用, 在這樣的背景下, 此書 的英譯版便顯得尤為及時。民族問題涉及到歷史與現實、國家與社會、經濟與文化等諸多因素, 非單一 因素使然。回中國經驗便是依據本國國情, 因時因地施以適當的策略, 妥善處理民族關係。中國要擁抱 世界, 世界也需要瞭解中國, 而世界瞭解中國, 除了親自來走一走、看一看, 主要還是通過各類介紹中國 風土人情的翻譯作品。因此, 以外國人更易接受的方式講好中國故事, 對中國、對世界都是大有禆益的。

\section{注釋}

(1) 黄友義: 《講好中國故事, 引領國際興論》,《公共外交季刊》2015 年第 8 期, 頁 54-58。

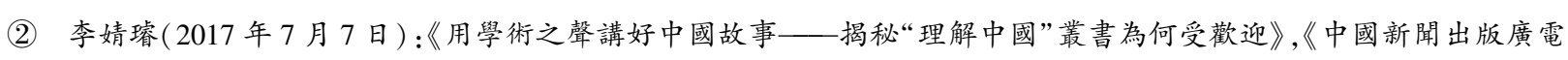
報》,取自 http://www.cssn.cn/ts/ts_sksy/201707/t20170707_3573192.shtml

(3) 黄友義:《通過主題圖書, 翻譯助力對外傳播》,《中國翻譯》2019 年第 5 期, 頁 5-8。

(4) 黄友義:《把握翻譯新䞨势, 抓住翻譯新機遇》,《當代外語研究》2018 年第 5 期, 頁 88-89。

(5) 馬玉梅:《中國學術著作海外傅播現狀與提升策略研究—以國家社科基金中華學衍外譯専案為例》, 《上海翻譯》 2019 年第 5 期, 頁 64-67。

(6) 孫窖㸘: 《翻譯研究的文化人類學緯度: 深度翻譯》,《上海翻譯》2010 年第 1 期, 頁 $14-17$ 。

(7) 張佩瑤:《從“軟實力”的角度自我剖析<中國翻譯話語英譯選集 (上冊) : 從最早期到佛典翻譯〉的選、譯、評、注》,《中 
國翻譯》2007 年第 6 期, 頁 36-41。

(8) 李雁: 《<紅樓莺>法譯本的“深度翻譯”及其文化傅遞》,《外語教學與研究》2014 年第 4 期,頁 616-624,641。

(9) 許明武、王煙朦:《任譯〈天工開物〉深度翻譯的“資本”視角解讀》,《中國翻譯》2017年第 1 期, 頁 92-97。

(10) 蔡名照 (2013 年 10 月 10 日): 《講好中國故事, 傅播好中國韾音》, 《人民網一人民日報》, 取自 http: //politics. people. com.cn/n/2013/1010/c1001-23144775.html

(11) 文軍、王斌: 《<芬尼根的守霝夜>深度翻譯研究》,《外國語文》2016 年第 1 期, 頁 110-116。

(12) 黄小艺:《再論深度翻譯的理諭和方法》, 《外語研究》2014 年第 2 期, 頁 74 。

(13) Hao, S. (2019). China's Solution to Its Ethno-National Issues. Berlin: Springer-Verlag.

(14) 曹明倫:《當令易曉, 勿失厥義——談嗳性深度翻譯的實用性》,《中國翻譯》2014年第 3 期, 頁 112-114。

(15) 黄小艺:《再諭深度翻譯的理論和方法》,《外語研究》2014 年第 2 期, 頁 75 。

(16) 朱健平、劉松: 《艾喬恩企鸡版<墨子>英譯中深度翻譯策略研究》,《外語教學》2019 年第 2 期, 頁 99-103。

(17) 黄友義: 《如何講好中國故事》,《公共外交季刊》2014 年第 4 期, 頁 51-55+132。

(18) 姚斌、Ursula Deser Friedman: «中文社科文獻外譯的挑戰、對策與建議—以<20世紀中國古代文化經典在域外的傅 播與影響研究>英譯為例》, 《中國翻譯》2019 年第 2 期, 頁 149-156。

(19) 關凱:《中國民族政策:歷史、理論與現實的挑戰》,《中央社會主義學院學報》2017 年第 2 期, 頁 47-53。 